\title{
Osteopathic graduate medical education
}

\author{
HELEN H. BAKER, PhD \\ JANICE WACHTLER, BA
}

This report summarizes important changes in osteopathic graduate medical education. The report also discusses the administration of graduate medical education by the AOA and presents current statistics regarding internships, residencies, and certification.

\section{Administration of graduate medical education in the AOA}

The Committee on Postdoctoral Training (COPT) was established by action of the AOA Board of Trustees in January 1968, to assure the Bureau of Professional Education, the AOA Board of Trustees, the osteopathic medical profession, and the general public that graduate medical programs were operating within approved standards, rules, and regulations, and providing educational training satisfactory to the public interest. The COPT was reorganized in 1990 and now consists of 23 members from affiliate organizations representing the major branches of osteopathic medicine, hospital administration, the uniformed services, and directors of medical education. (See Appendix I, page 1153.)

The COPT works through the Division of Postdoctoral Training of the AOA Department of Education to regulate and monitor graduate medical training in osteopathic medical institutions and evaluate graduate medical training taken in the military and approved allopathic locations. This is done through reports and inspections of training programs which are then reviewed by the Committee at its meetings in April and November each year. Recommendations from the COPT are sent to the

Dr Baker is associate director of the AOA Department of Education and secretary to the Committee on Postdoctoral Training and the Advisory Board for Osteopathic Specialists. Ms Wachtler is administrator for the Division of Postdoctoral Education.

Reprint requests to Dr Baker, AOA Department of Education, 142 E Ontario St, Chicago, IL 60611-2864.

Bureau of Professional Education and the AOA Board of Trustees for approval. Items that are recommended for denial by the COPT may be appealed to the Bureau of Professional Education before presentation to the Board of Trustees. The approval and appeal processes and other policies regarding graduate medical training are published annually by the AOA Department of Education and are available on request.

\section{Osteopathic intern programs and positions}

\section{Trends in enrollment}

In the early 1980 s, the osteopathic profession did not have enough osteopathic intern positions to meet the needs of osteopathic graduates. In the past few years, the number of intern positions expanded, while the number of students projected as graduating each year decreased slightly. Table 1 shows the number of osteopathic intern positions and the projected number of graduates available to fill those positions. Figures 1, 2, and 3 are drawn from these data.

Figure 1 shows that the percentage of students who took internships has remained relatively stable, with about $82 \%$ of graduating students taking internships in osteopathic institutions for the past 4 years.

Figure 2 shows that the number of approved intern positions has increased $23 \%$ from 19841985 to $1991-1992$. Similarly, the number of funded positions has increased, with a drop in number funded in 1991-1992.

Figure 3 shows the gap that resulted from the decline in graduates and increase in funded positions. In 1991-1992, only $76 \%$ of funded positions were filled, compared with 99\% in 1984-1985.

Table 2 addresses concerns regarding interns who fail to honor their intern program 
Table 1

Approved, Funded, and Filled Intern Positions, and

Number of Graduates Available to Fill Those Positions, 1984-1985 Through 1991-1992

\begin{tabular}{|c|c|c|c|c|c|c|c|c|c|}
\hline & \multicolumn{8}{|c|}{ Year } & \multirow{2}{*}{$\begin{array}{c}\text { \% Change } \\
1984-1985 \\
\text { to } \\
1991-1992\end{array}$} \\
\hline & $\begin{array}{l}1984- \\
1985\end{array}$ & $\begin{array}{l}1985- \\
1986\end{array}$ & $\begin{array}{l}1986- \\
1987\end{array}$ & $\begin{array}{l}1987- \\
1988\end{array}$ & $\begin{array}{l}1988- \\
1989\end{array}$ & $\begin{array}{l}1989- \\
1990\end{array}$ & $\begin{array}{l}1990- \\
1991\end{array}$ & $\begin{array}{l}1991- \\
1992\end{array}$ & \\
\hline Approved positions & 1,579 & 1,643 & 1,660 & 1,774 & 1,845 & 1,859 & 1,859 & 1,942 & 23 \\
\hline Graduates & 1,474 & 1,589 & 1,584 & 1,581 & 1,612 & 1,528 & 1,537 & 1,523 & 3 \\
\hline Funded positions & 1,309 & 1,378 & 1,387 & 1,490 & 1,515 & 1,622 & 1,701 & 1,648 & 26 \\
\hline Filled positions & 1,299 & 1,357 & 1,330 & 1,354 & 1,329 & 1,248 & 1,248 & 1,254 & -3 \\
\hline $\begin{array}{l}\text { Graduates taking osteo- } \\
\text { pathic internships, \% }\end{array}$ & 88 & 85 & 84 & 85 & 82 & 82 & 81 & 82 & \\
\hline $\begin{array}{l}\text { Funded intern positions } \\
\text { that were filled, } \%\end{array}$ & 99 & 98 & 96 & 91 & 88 & 77 & 73 & 76 & \\
\hline
\end{tabular}

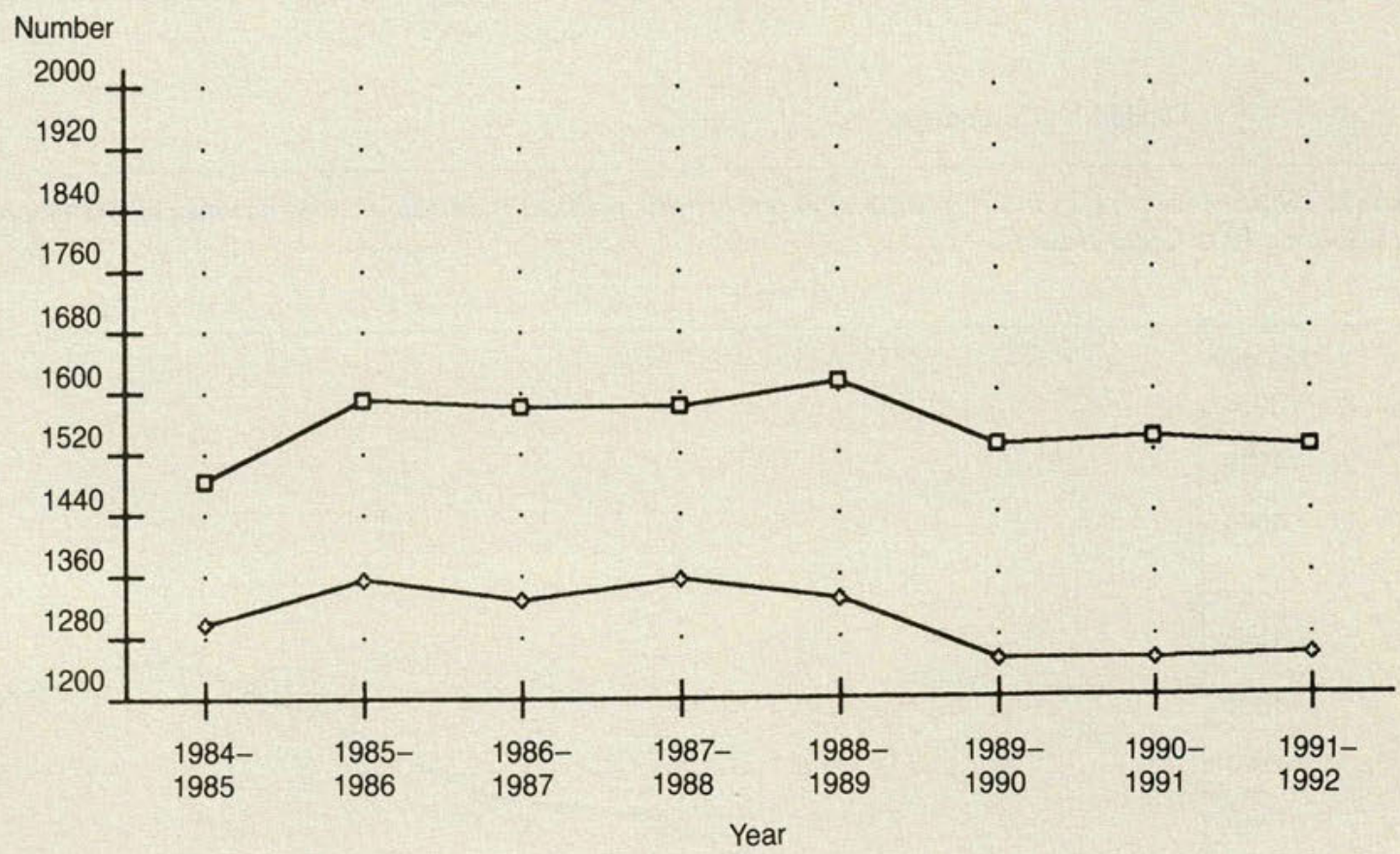

$\triangle$ Filled $\quad \square$ Projected number of graduates

Figure 1. Number of osteopathic intern positions filled, and number of DOs projected to graduate each year. (Source: AOA Data Base.)

commitments. The percentage of graduates breaking contracts has continued to decline.

Table 3 lists intern positions and their geographic locations for 1989-1990 through 19911992. The seven states with the most positions-Michigan, Pennsylvania, Ohio, New York, New Jersey, Illinois, and Florida-con- tain $77 \%$ of the filled intern positions. Initiatives are under way to focus expansion of intern programs on "small states" and states for which there is an unmet demand for intern positions.

The AOA approves intern programs in AOAaccredited hospitals and programs sponsored 


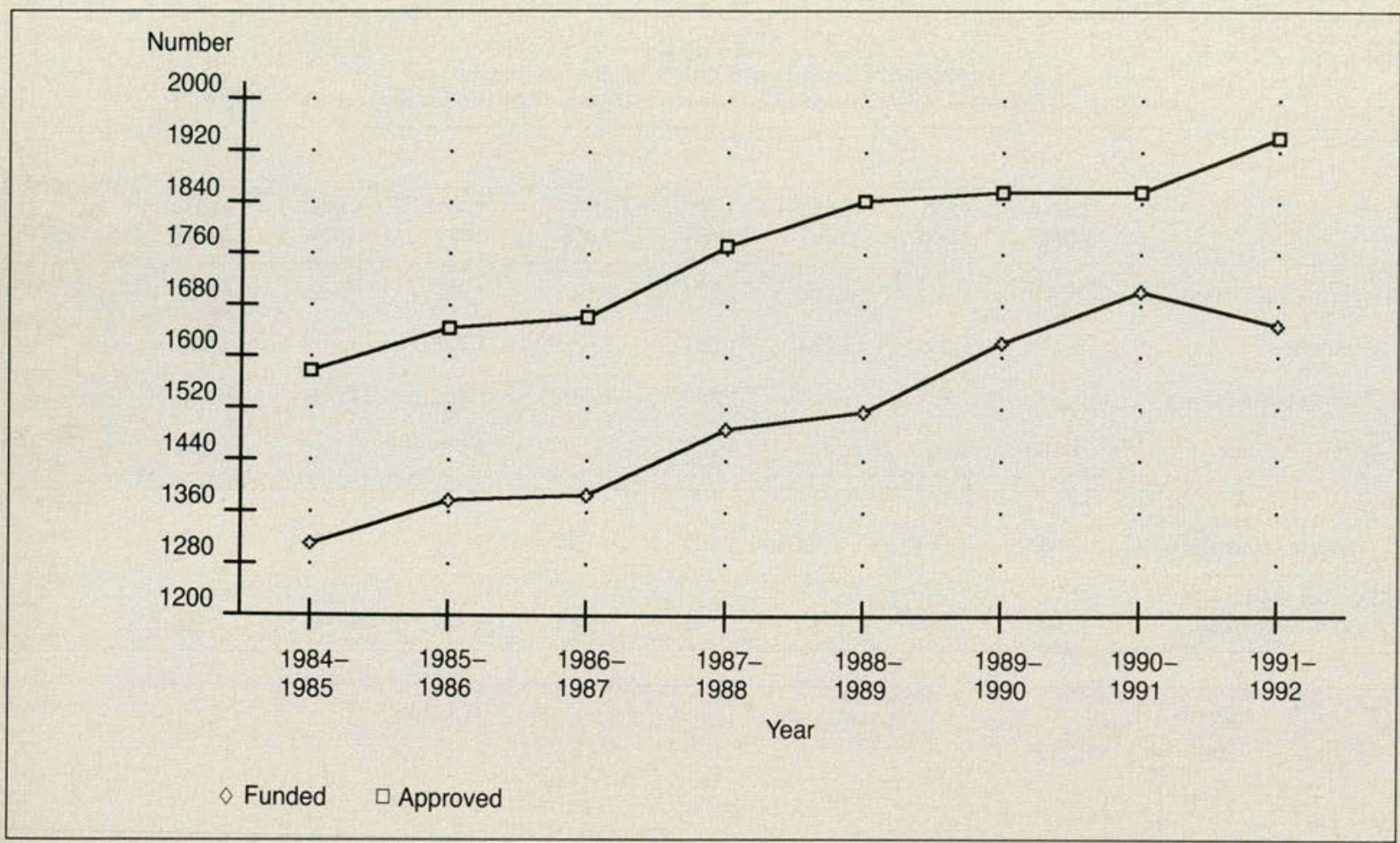

Figure 2. Number of funded intern positions in osteopathic medical institutions, and number of AOA-approved positions. (Source: AOA Data Base.)

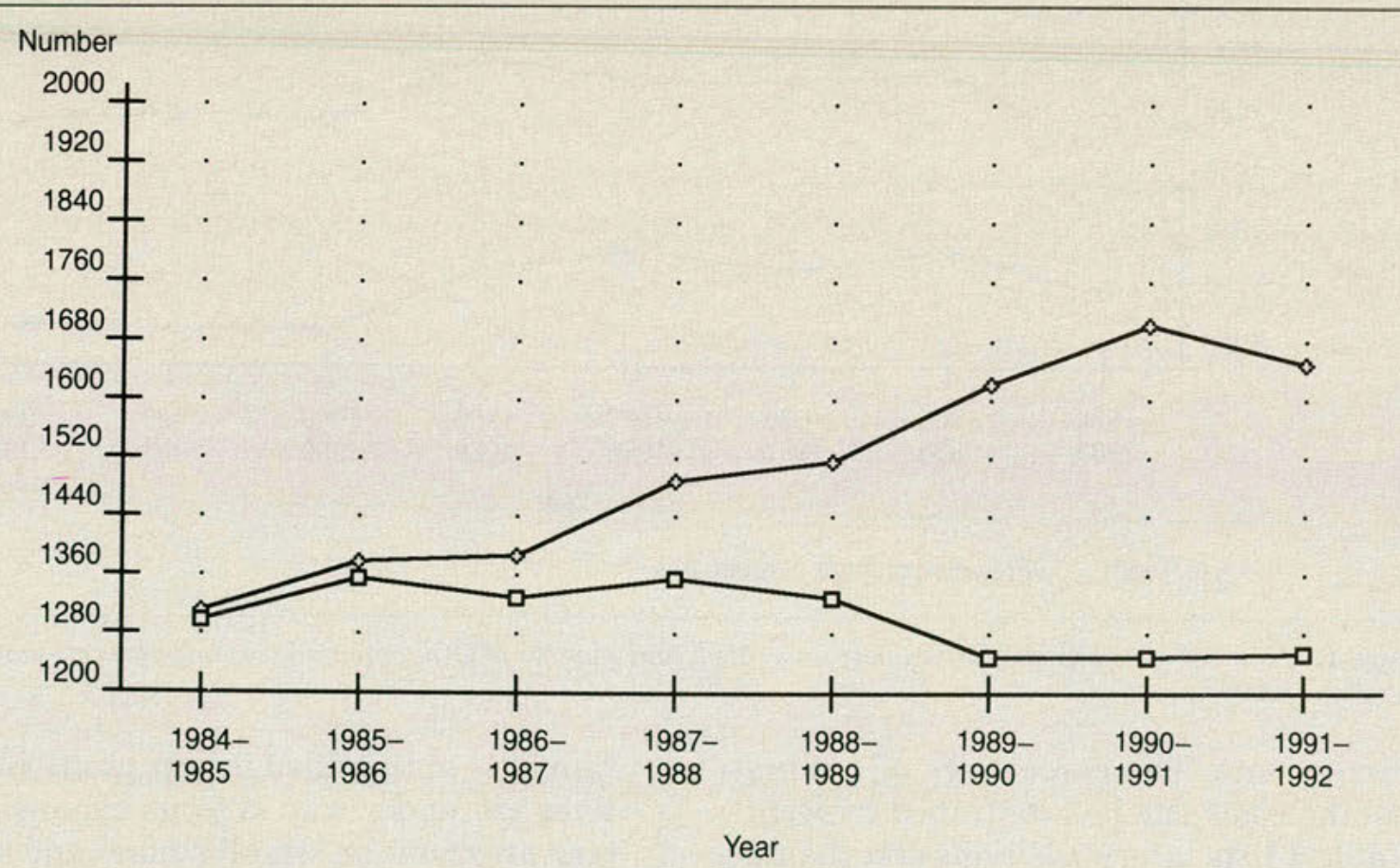

$\diamond$ Funded $\quad \square$ Filled

Figure 3. Number of intern positions filled, and number of funded intern positions in osteopathic medical institutions. (Source: AOA Data Base.) 


\begin{tabular}{|c|c|c|c|c|}
\hline \multicolumn{5}{|c|}{$\begin{array}{c}\text { Table } 2 \\
\text { Intern Contract Releases/Violations }\end{array}$} \\
\hline & \multicolumn{2}{|c|}{$1990-1991$} & \multicolumn{2}{|r|}{ 1991-1992 } \\
\hline & No. & $\begin{array}{l}\text { Percent of } \\
\text { those available } \\
\text { to participate } \\
\text { in the match }\end{array}$ & No. & $\begin{array}{l}\text { Percent of } \\
\text { those available } \\
\text { to participate } \\
\text { in the match }\end{array}$ \\
\hline $\begin{array}{l}\text { Contract releases by } \\
\text { mutual consent: }\end{array}$ & & & & \\
\hline To take other DO programs & 11 & & 3 & \\
\hline To take allopathic programs & 17 & & 10 & \\
\hline To take military programs & 2 & & 0 & \\
\hline Reasons unknown & 1 & & 0 & \\
\hline Total mutual releases & 31 & $2.0 \%$ & 13 & $0.09 \%$ \\
\hline Reported contract breaches: & & & & \\
\hline To take allopathic programs & 4 & & 5 & \\
\hline Reasons unknown & 0 & & 0 & \\
\hline Total known breaches & 4 & $0.3 \%$ & 5 & $0.03 \%$ \\
\hline Total releases and breaches & 35 & $2.3 \%$ & 18 & $1.30 \%$ \\
\hline
\end{tabular}

Table 3

AOA-Approved Osteopathic Intern Positions, by State

\begin{tabular}{|c|c|c|c|c|c|c|c|c|c|}
\hline \multirow[b]{2}{*}{ State } & \multicolumn{3}{|c|}{$1989-1990$} & \multicolumn{3}{|c|}{$1990-1991$} & \multicolumn{3}{|c|}{ 1991-1992 } \\
\hline & Approved & Funded & Filled & Approved & Funded & Filled & Approved & Funded & Filled \\
\hline Arizona & 40 & 18 & 13 & 40 & 27 & 18 & 26 & 14 & 12 \\
\hline California & 66 & 39 & 32 & 64 & 49 & 42 & 59 & 36 & 26 \\
\hline Colorado & 9 & 8 & 7 & 9 & 9 & 9 & 25 & 15 & 15 \\
\hline Delaware & 6 & 6 & 6 & 6 & 6 & 3 & 6 & 6 & 4 \\
\hline Florida & 112 & 96 & 82 & 112 & 98 & 76 & 113 & 101 & 70 \\
\hline Georgia & 10 & 5 & 4 & 10 & 7 & 6 & 10 & 7 & 5 \\
\hline Illinois & 90 & 87 & 80 & 90 & 75 & 56 & 90 & 86 & 76 \\
\hline Indiana & 17 & 17 & 15 & 17 & 17 & 11 & 28 & 20 & 10 \\
\hline Iowa & 28 & 16 & 15 & 28 & 21 & 18 & 17 & 17 & 10 \\
\hline Kansas & 12 & 9 & 7 & 12 & 9 & 7 & 12 & 12 & 9 \\
\hline Maine & 22 & 19 & 18 & 19 & 19 & 15 & 30 & 22 & 17 \\
\hline Massachusetts & 4 & 4 & 3 & 0 & 0 & 0 & 0 & 0 & 0 \\
\hline Michigan & 326 & 300 & 263 & 344 & 321 & 262 & 376 & 340 & 264 \\
\hline Missouri & 86 & 67 & 57 & 86 & 65 & 48 & 86 & 57 & 39 \\
\hline New Jersey & 124 & 92 & 86 & 127 & 110 & 97 & 142 & 119 & 109 \\
\hline New Mexico & 0 & 0 & 0 & 0 & 0 & 0 & 0 & 0 & 0 \\
\hline New York & 194 & 161 & 132 & 218 & 186 & 136 & 217 & 184 & 122 \\
\hline Ohio & 198 & 178 & 164 & 198 & 171 & 137 & 198 & 176 & 131 \\
\hline Oklahoma & 76 & 61 & 56 & 76 & 59 & 44 & 76 & 54 & 45 \\
\hline Oregon & 7 & 6 & 6 & 7 & 6 & 6 & 7 & 6 & 6 \\
\hline Pennsylvania & 260 & 213 & 202 & 260 & 249 & 179 & 284 & 250 & 188 \\
\hline Rhode Island & 7 & 6 & 2 & 7 & 7 & 7 & 8 & 8 & 8 \\
\hline Texas & 88 & 63 & 56 & 80 & 71 & 46 & 87 & 79 & 66 \\
\hline Virginia & 0 & 0 & 0 & 0 & 0 & 0 & 11 & 11 & 5 \\
\hline Washington & 0 & 0 & 0 & 0 & 0 & 0 & 0 & 0 & 0 \\
\hline West Virginia & 44 & 35 & 19 & 44 & 35 & 22 & 29 & 23 & 15 \\
\hline Wisconsin & 15 & 9 & 4 & 5 & 5 & 3 & 5 & 5 & 2 \\
\hline Subtotal & $\overline{1,841}$ & $\overline{1,515}$ & $\overline{1,329}$ & $\overline{1,859}$ & $\overline{1,622}$ & $\overline{1,248}$ & $\overline{1,942}$ & $\overline{1,648}$ & $\overline{1,254}$ \\
\hline Military & & & 61 & & & 45 & & & 50 \\
\hline Special Approvals & & & 37 & & & 4 & & & 9 \\
\hline Total & & & $\overline{1,427}$ & & & 1,297 & & & $\overline{1,313}$ \\
\hline
\end{tabular}


by AOA-accredited institutions, in hospitals that may or may not be accredited by the AOA. As of Sept 1, 1991, there were 997 (79\%) interns in programs in AOA-accredited hospitals not sponsored by colleges of osteopathic medicine (COMs); 52 (4\%) in COM-sponsored programs in AOA-accredited hospitals; and $212(17 \%)$ in COM-sponsored programs in hospitals not accredited by the AOA. Regarding the percentage of funded positions that was filled, AOA-accredited hospitals without college sponsorship had 78\% filled; COM-sponsored programs in AOA-accredited hospitals had $73 \%$ filled; and COM-sponsored programs in hospitals not accredited by the AOA had $74 \%$ filled.

\section{Specialty programs in the internship}

In 1990, the AOA Board of Trustees adopted policies creating "specialty programs" within the osteopathic internship. In 1991, the Board further clarified terminology for these programs. "Specialty internships" refer to programs that may be acceptable as the first year of graduate medical training within the specialty. Such specialty internships are available in internal medicine and obstetrics and gynecology. Specialty internships must be conducted at institutions that have AOA-approved residency training in these specialties.

"Special emphasis internship" refers to concentration in a specialty, but no reduction in total number of years of training. Such programs were approved in general practice and pediatrics in 1990, and in emergency medicine in 1991. The expectation is that these curricula will both enhance the quality of specialty training and attract more students to general practice, pediatrics, and emergency medicine.

All models for the internship, including all specialty tracks, continue to include rotational requirements in general practice, surgery, internal medicine, pediatrics, and female reproductive medicine, and continue to include the requirement that osteopathic principles and practices be incorporated throughout the internship. Furthermore, an AOA-approved internship remains the basis for any further approval of graduate medical training by the $\mathrm{AOA}$. If a COM graduate enters allopathic resi- dency training directly on graduation from a $\mathrm{COM}$, that residency training cannot be approved.

On Oct 1, 1991, there were 145 interns enrolled in specialty or special emphasis programs for the 1991-1992 internship year. Of these 145 interns, 83 were in internal medicine; 16 in obstetrics/gynecology; 40 in general practice; and 9 in pediatrics. In comparison, 64 interns completed such programs in $1990-1991$, the first year of specialty and special emphasis programs, when 26 completed internal medicine; 18, obstetrics/gynecology; 16 , general practice; and 4 , pediatrics. No interns are currently enrolled in the new special emphasis program in emergency medicine.

In spring 1991, the Department of Education conducted a survey of directors of medical education, to which $64 \%$ of the directors responded. This survey indicated that at the conclusion of the year, $80 \%$ of those interns in the specialty intern program in obstetrics/ gynecology were remaining at that institution in that specialty. In contrast, in internal medicine, $39 \%$ of the specialty interns were continuing in internal medicine residencies at the same institution. In general practice, $47 \%$ of the special emphasis interns were remaining at the institution for general practice residencies, and in pediatrics, neither of the two special emphasis interns remained for pediatrics residencies at the same institution.

\section{Residency training policies and programs Enrollment in osteopathic residency training}

In $1985-1986$, there were a total of 1,245 residents in programs in osteopathic medical institutions. Based on contracts received by the AOA Division on Postdoctoral Training by Sept 1, 1991, there are 1,725 residents in osteopathic medical institutions in 1991-1992. This number is a $38.6 \%$ increase for the 6 year period and an $11.2 \%$ increase from 1990 1991. Data for all residencies are shown in Table 4 .

Figure 4 shows enrollment for the past 4 years for those specialties with the highest number of residents (combining all medical specialties and combining Radiology and Diagnos- 
Table 4

Residency Programs in Osteopathic Medical Institutions*

\begin{tabular}{|c|c|c|c|c|c|c|c|c|c|c|c|c|}
\hline \multirow[b]{2}{*}{ Specialty } & \multicolumn{3}{|c|}{ 1988-1989 } & \multicolumn{3}{|c|}{$1989-1990$} & \multicolumn{3}{|c|}{$1990-1991$} & \multicolumn{3}{|c|}{ 1991-1992 } \\
\hline & $\begin{array}{l}\text { Pro- } \\
\text { grams }\end{array}$ & $\begin{array}{l}\text { Posi- } \\
\text { tions }\end{array}$ & $\begin{array}{l}\text { Resi- } \\
\text { dents }\end{array}$ & $\begin{array}{l}\text { Pro- } \\
\text { grams }\end{array}$ & $\begin{array}{l}\text { Posi- } \\
\text { tions }\end{array}$ & $\begin{array}{l}\text { Resi- } \\
\text { dents }\end{array}$ & $\begin{array}{l}\text { Pro- } \\
\text { grams }\end{array}$ & $\begin{array}{l}\text { Posi- } \\
\text { tions }\end{array}$ & $\begin{array}{l}\text { Resi- } \\
\text { dents }\end{array}$ & $\begin{array}{l}\text { Pro- } \\
\text { grams }\end{array}$ & $\begin{array}{l}\text { Posi- } \\
\text { tions }\end{array}$ & $\begin{array}{l}\text { Resi- } \\
\text { dents }\end{array}$ \\
\hline Anesthesiology & 33 & 124 & 90 & 31 & 129 & 76 & 29 & 138 & 86 & 29 & 150 & 95 \\
\hline Dermatology & 2 & 4 & 5 & 2 & 4 & 4 & 3 & 8 & 6 & 6 & 18 & 9 \\
\hline Emergency Medicine & 16 & 123 & 85 & 16 & 149 & 119 & 16 & 174 & 132 & 19 & 233 & 198 \\
\hline General Practice & 72 & 452 & 318 & 81 & 658 & 315 & 87 & 708 & 408 & 94 & 795 & 368 \\
\hline Geriatrics & $\ldots$ & $\ldots$ & ... & $\ldots$ & $\ldots$ & $\ldots$ & 1 & 4 & 2 & 1 & 4 & 2 \\
\hline Internal Medicine & 49 & 358 & 261 & 45 & 343 & 214 & 45 & 365 & 205 & 45 & 372 & 218 \\
\hline Allergy/Immunology & 0 & 0 & 0 & 0 & 0 & 0 & 0 & 0 & 0 & 0 & 0 & 0 \\
\hline Cardiology & 10 & 27 & 10 & 12 & 37 & 13 & 11 & 36 & 12 & 13 & 46 & 20 \\
\hline Endocrinology & 1 & 1 & 0 & 1 & 2 & 1 & 1 & 2 & 1 & 2 & 4 & 0 \\
\hline Gastroenterology & 6 & 16 & 9 & 5 & 15 & 11 & 5 & 16 & 9 & 6 & 20 & 16 \\
\hline Hematology & 2 & 6 & 2 & 1 & 2 & 1 & 1 & 2 & 0 & 1 & 2 & 0 \\
\hline Hematoloty/Oncology & 2 & 4 & 0 & 1 & 2 & 0 & 1 & 2 & 0 & 1 & 2 & 1 \\
\hline Infectious Diseases & 3 & 6 & 1 & 2 & 4 & 3 & 3 & 5 & 3 & 1 & 7 & 3 \\
\hline Nephrology & 4 & 10 & 0 & 1 & 4 & 0 & 1 & 4 & 1 & 1 & 2 & 1 \\
\hline Oncology & 0 & 0 & 0 & 0 & 0 & 0 & 0 & 0 & 0 & 1 & 2 & 1 \\
\hline Pulmonary Medicine & 8 & 18 & 11 & 8 & 18 & 6 & 9 & 20 & 6 & 10 & 24 & 12 \\
\hline Rheumatology & 1 & 1 & 0 & 1 & 1 & 0 & 1 & 1 & 0 & 1 & 1 & 0 \\
\hline $\begin{array}{l}\text { Internal Medicine/ } \\
\text { Emergency Medicine }\end{array}$ & & & & & $\cdots$ & $\cdots$ & $\cdots$ & $\cdots$ & $\cdots$ & 1 & 8 & 2 \\
\hline Neurology & 5 & 13 & 12 & 4 & 13 & 7 & 4 & 13 & 10 & 4 & 16 & 16 \\
\hline Child Neurology & 0 & 0 & 0 & 0 & 0 & 0 & 0 & 0 & 0 & 0 & 0 & 0 \\
\hline Nuclear Medicine & 2 & 3 & 0 & 0 & 0 & 0 & 0 & 0 & 0 & 0 & 0 & 0 \\
\hline Obstetrics/Gynecology & 37 & 127 & 110 & 28 & 134 & 125 & 29 & 147 & 110 & 31 & 165 & 146 \\
\hline $\begin{array}{l}\text { Maternal/ } \\
\text { Fetal Medicine }\end{array}$ & $\ldots$ & $\ldots$ & $\cdots$ & $\cdots$ & $\cdots$ & $\ldots$ & ... & $\cdots$ & $\cdots$ & 1 & 2 & 0 \\
\hline Ophthalmology & 15 & 41 & 30 & 16 & 44 & 32 & 15 & 42 & 36 & 16 & 51 & 38 \\
\hline Orthopedic Surgery & 34 & 138 & 120 & 33 & 142 & 129 & 33 & 153 & 130 & 33 & 161 & 146 \\
\hline $\begin{array}{l}\text { Osteopathic Principles } \\
\text { and Practice }\end{array}$ & 8 & 28 & 5 & 8 & 30 & 4 & 8 & 31 & 4 & 8 & 31 & 3 \\
\hline Otorhinolaryngology & 4 & 8 & 5 & 2 & 6 & 4 & 2 & 6 & 4 & 2 & 6 & 6 \\
\hline $\begin{array}{l}\text { Otorhinolaryngology/ } \\
\text { Orofacial Plastic Surgery }\end{array}$ & 16 & & & & & & & & & & & \\
\hline $\begin{array}{l}\text { Orofacial Plastic Surgery } \\
\text { Anatomic Pathology }\end{array}$ & $\begin{array}{l}16 \\
18\end{array}$ & $\begin{array}{l}51 \\
43\end{array}$ & $\begin{array}{l}36 \\
12\end{array}$ & 16 & 54 & 41 & 16 & 57 & 46 & $\begin{array}{r}16 \\
8\end{array}$ & $\begin{array}{l}57 \\
24\end{array}$ & $\begin{array}{r}44 \\
3\end{array}$ \\
\hline Pediatrics & 15 & $\begin{array}{l}43 \\
71\end{array}$ & $\begin{array}{l}12 \\
27\end{array}$ & 8 & 24 & 6 & 7 & 22 & $\begin{array}{l}3 \\
7\end{array}$ & $\begin{array}{r}8 \\
10\end{array}$ & $\begin{array}{l}24 \\
48\end{array}$ & $\begin{array}{l}3 \\
3\end{array}$ \\
\hline Neonatal Medicine & 2 & 6 & $\begin{array}{r}27 \\
0\end{array}$ & $\begin{array}{l}9 \\
2\end{array}$ & $\begin{array}{r}48 \\
6\end{array}$ & $\begin{array}{r}15 \\
1\end{array}$ & $\begin{array}{r}10 \\
2\end{array}$ & $\begin{array}{r}48 \\
6\end{array}$ & 2 & 2 & $\begin{array}{r}40 \\
6\end{array}$ & 1 \\
\hline Public Health/Preventive & & & & & & & & & & & & \\
\hline $\begin{array}{l}\text { Medicine } \\
\text { Proctology }\end{array}$ & 1 & 2 & 0 & 0 & 0 & 0 & 0 & 0 & 0 & 1 & $4^{-}$ & 0 \\
\hline $\begin{array}{l}\text { Proctology } \\
\text { Psychiatry }\end{array}$ & 4 & 6 & 1 & $\begin{array}{l}3 \\
6\end{array}$ & 5 & 1 & 3 & 5 & 2 & 3 & 5 & 4 \\
\hline $\begin{array}{l}\text { Psychiatry } \\
\text { Child Psychiatry }\end{array}$ & 5 & 36 & 29 & $\begin{array}{l}6 \\
2\end{array}$ & 50 & 32 & 7 & 64 & 41 & 7 & 76 & 47 \\
\hline & 2 & 4 & 0 & 2 & 4 & 0 & 2 & 4 & 0 & 3 & 6 & 1 \\
\hline & $\begin{array}{r}15 \\
1\end{array}$ & 72 & 15 & $\begin{array}{r}14 \\
0\end{array}$ & 71 & 36 & 15 & 63 & 31 & 15 & 65 & 61 \\
\hline & $\begin{array}{l}1 \\
1\end{array}$ & 2 & 0 & $\begin{array}{l}0 \\
1\end{array}$ & 0 & 0 & 0 & 0 & 0 & 0 & 0 & 0 \\
\hline $\begin{array}{l}\text { Neuroradiology } \\
\text { Nuclear Radiology }\end{array}$ & $\begin{array}{l}1 \\
1\end{array}$ & 1 & 0 & 1 & 1 & 0 & 1 & 1 & 0 & 0 & 0 & 0 \\
\hline & $\begin{array}{l}1 \\
2\end{array}$ & 2 & 0 & $\begin{array}{l}1 \\
2\end{array}$ & 1 & 1 & 1 & 1 & 1 & 1 & 1 & 0 \\
\hline & $\begin{array}{l}2 \\
1\end{array}$ & 4 & 1 & $\begin{array}{l}2 \\
1\end{array}$ & 4 & 1 & 2 & 4 & 2 & 2 & 4 & 1 \\
\hline Pedicine & 1 & 1 & 0 & 1 & 1 & 0 & 1 & 1 & 0 & 0 & 0 & 0 \\
\hline Rehabilitation Medicine & 2 & 6 & 3 & 1 & 3 & 0 & 0 & 0 & 0 & 0 & 0 & 0 \\
\hline $\begin{array}{l}\text { Surgery } \\
\text { General }\end{array}$ & 53 & 223 & 196 & 47 & 219 & 168 & 48 & 235 & 172 & 48 & 238 & 185 \\
\hline General Vascular & 3 & 6 & 1 & 3 & 7 & 0 & 5 & 10 & 2 & 5 & 10 & 2 \\
\hline Neurological & 6 & 14 & 10 & 8 & 19 & 9 & 8 & 19 & 11 & 8 & 20 & 10 \\
\hline $\begin{array}{l}\text { Plastic and } \\
\text { Reconstructive }\end{array}$ & 0 & 0 & 0 & 0 & 0 & 0 & 0 & 0 & 0 & 1 & 2 & 2 \\
\hline $\begin{array}{l}\text { Thoracic/ } \\
\text { Cardiovascular }\end{array}$ & 2 & 5 & 0 & 2 & 5 & 2 & 2 & 5 & 2 & 2 & 5 & 1 \\
\hline $\begin{array}{l}\text { Cardiovascular } \\
\text { Urological }\end{array}$ & 14 & 31 & 16 & 10 & 27 & 16 & 10 & 27 & 17 & 11 & 30 & 17 \\
\hline Total & 490 & $\overline{2,146}$ & $\overline{1,480}$ & $\overline{442}$ & $\overline{2,335}$ & $\overline{1,428}$ & $\overline{453}$ & $\overline{2,498}$ & $\overline{1,551}$ & 477 & $\overline{2,772}$ & $\overline{1,725}$ \\
\hline
\end{tabular}

*This table reports on residency programs, approved positions, and resident training in osteopathic medical institutions. These data, current to Sept 1,1991 , reflect only those residency contracts received to that date. 


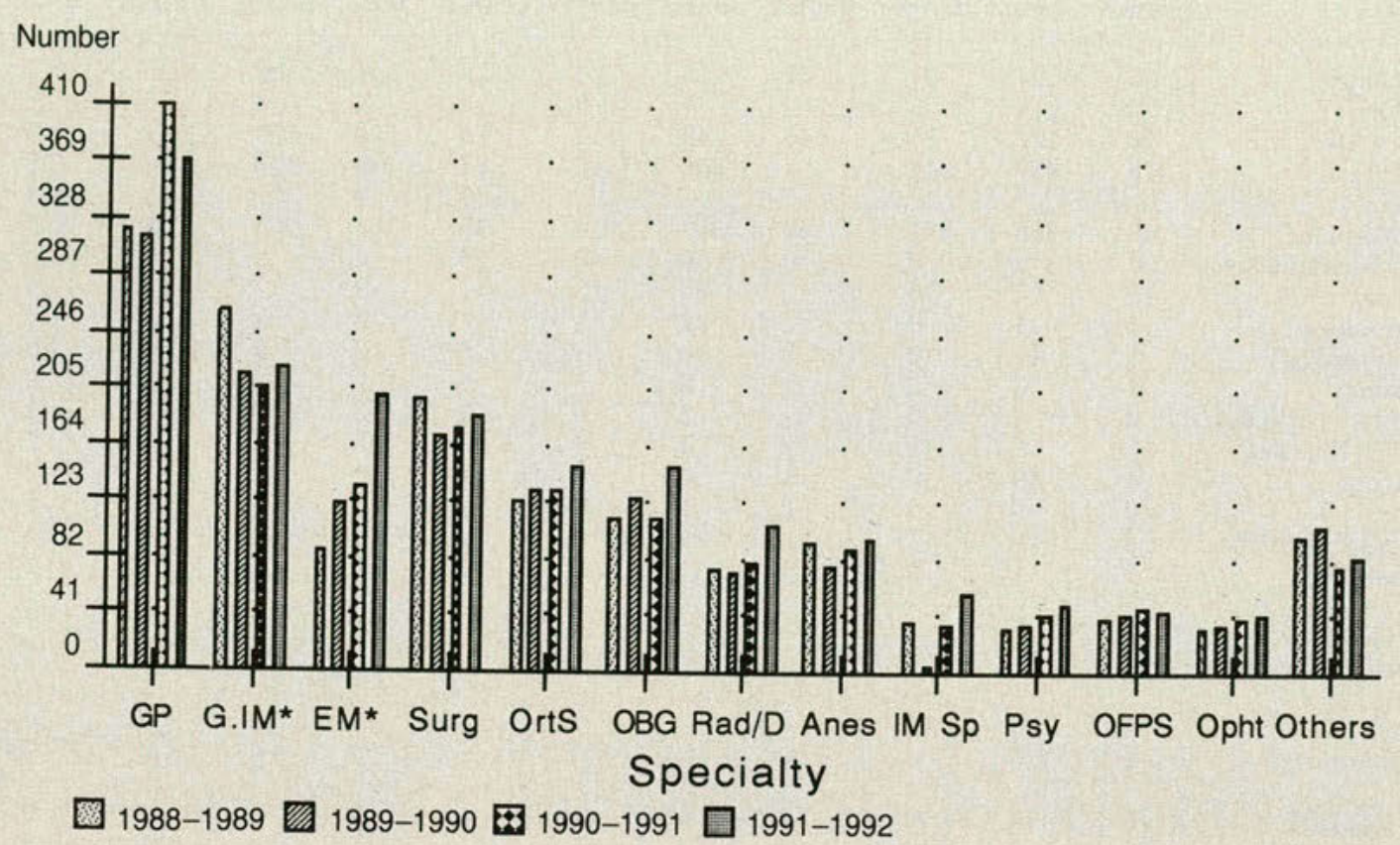

Figure 4. Enrollment in osteopathic residencies, selected specialties, ordered by enrollmment in 1991-1992. (Source: AOA Data Base.) *Does not include 2 residents in combined internal medicine/emergency medicine programs in 1991 1992. (Key: $G P=$ general practice; $G I M=$ general internal medicine; $E M=$ emergency medicine; Surg = general surgery; OrtS = orthopedic surgery; $O B G=$ obstetrics and gynecology; Rad $/ D=$ radiology and diagnostic radiology [combined]; Anes = anesthesiology; IM Sp = internal medicine specialties other than general internal medicine; Psy = psychiatry; OFPS = orofacial and plastic surgery; Opht = ophthalmology.)

tic Radiology). These data show a distressing drop in the number of general practice residents. For general practice, 1990-1991 was the first year of the requirement of a second year of this residency, so a stable rate of enrollment would have resulted in a doubling of the numbers in this residency program. Instead, these data show only a slight increase in 1990-1991, followed by a $10 \%$ drop for the current year. Furthermore, pediatrics (combined in the "other" statistics in this illustration) continued its decline in enrollment, with 27 residents in 1988-1989; 15 in 1989-1990; 7 in 1990-1991; and only 3 in 1991-1992.

Most other areas, however, show an increase. Internal medicine specialties showed a $69 \%$ increase from last year, with increases from 12 to 20 residents in cardiology; 9 to 16 in gastroenterology; and 6 to 12 in pulmonary medicine. Enrollment in emergency medicine increased $50 \%$ in the year, through both new programs and increases in the size of existing programs, to now be the profession's third largest residency area.

Obstetrics and gynecology programs gained $33 \%$ this year. Some of this increase may be attributable to residents who had previously served in a specialty internship in obstetrics/ gynecology. (Specialty interns are included in intern data, but not in residency data.) General internal medicine, the other specialty that had a specialty internship that could count as the first year of residency, showed an $8 \%$ gain.

\section{Enrollment in allopathic residency programs}

Table 5 and Figure 5 compare enrollment in osteopathic residency programs with enrollment in allopathic residency programs. In 1987$1988,39 \%$ of the DOs in residency training were in osteopathic residency programs. In $1988-1989$, that percentage rose slightly to 
Table 5

DOs in Allopathic or Osteopathic Graduate Medical Training

\begin{tabular}{|c|c|c|c|c|c|c|}
\hline \multirow[b]{2}{*}{$\begin{array}{c}\text { Year } \\
\text { and } \\
\text { program }\end{array}$} & \multicolumn{6}{|c|}{ DOs } \\
\hline & Residents & $\begin{array}{c}\% \text { of } \\
\text { residents } \\
\text { in osteopathic } \\
\text { programs }\end{array}$ & $\begin{array}{l}\text { Rate of } \\
\text { increase }\end{array}$ & Interns* & $\begin{array}{l}\text { No. of } \\
\text { interns } \\
\text { plus } \\
\text { residents }\end{array}$ & $\begin{array}{c}\% \text { of all } \\
\text { trainees in } \\
\text { osteopathic } \\
\text { programs }\end{array}$ \\
\hline $\begin{array}{l}\text { 1985-1986 } \\
\text { Osteopathic } \dagger \\
\text { Allopathic } \ddagger\end{array}$ & $\begin{array}{l}1,245 \\
1,277\end{array}$ & $49 \%$ & $\ldots$ & 1,299 & 2,544 & $67 \%$ \\
\hline $\begin{array}{l}\text { 1986-1987 } \\
\text { Osteopathic } \dagger \\
\text { Allopathic } \ddagger\end{array}$ & $\begin{array}{l}1,250 \\
1,543\end{array}$ & $45 \%$ & $\begin{array}{r}0.4 \% \\
20.8 \%\end{array}$ & 1,357 & 2,607 & $63 \%$ \\
\hline $\begin{array}{l}\text { 1987-1988 } \\
\text { Osteopathic } \\
\text { Allopathic } \S\end{array}$ & $\begin{array}{l}1,290 \\
2,031\end{array}$ & $39 \%$ & $\begin{array}{r}3.2 \% \\
31.6 \%\end{array}$ & 1,330 & 2,620 & $56 \%$ \\
\hline $\begin{array}{l}\text { 1988-1989 } \\
\text { Osteopathic } \dagger \\
\text { Allopathic }\end{array}$ & $\begin{array}{l}1,480 \\
2,150\end{array}$ & $41 \%$ & $\begin{array}{r}14.7 \% \\
5.9 \%\end{array}$ & 1,354 & 2,834 & $57 \%$ \\
\hline $\begin{array}{l}\text { 1989-1990 } \\
\text { Osteopathic } \dagger \\
\text { Allopathic }\end{array}$ & $\begin{array}{l}1,430 \\
2,449\end{array}$ & $37 \%$ & $\begin{array}{l}-3.4 \% \\
13.9 \%\end{array}$ & 1,329 & 2,759 & $53 \%$ \\
\hline $\begin{array}{l}\text { 1990-1991 } \\
\text { Osteopathic } \dagger \\
\text { Allopathic\| }\end{array}$ & $\begin{array}{l}1,551 \\
2,872\end{array}$ & $35 \%$ & $\begin{array}{r}8.5 \% \\
17.3 \%\end{array}$ & 1,248 & 2,799 & $49 \%$ \\
\hline $\begin{array}{l}\text { 1991-1992 } \\
\text { Osteopathic } \dagger \\
\text { Allopathic }\end{array}$ & $\begin{array}{c}1,725 \\
\cdots\end{array}$ & $\begin{array}{l}\cdots \\
\cdots\end{array}$ & $\begin{array}{c}11.2 \\
\ldots\end{array}$ & $\begin{array}{c}1,244 \\
\ldots\end{array}$ & $\begin{array}{l}\cdots \\
\cdots\end{array}$ & $\ldots$ \\
\hline $\begin{array}{l}\text { *New graduates } \\
\text { +Source: AOA D } \\
\text { +Source: JAMA } \\
\text { \$Source: JAMA } \\
\text { |Source: JAMA }\end{array}$ & $\begin{array}{l}\text { ical institutions } \\
\text { sue, vol } 258, \mathrm{~N} \\
\text { sue, vol } 264, \mathrm{~N} \\
\text { sue, vol } 266, \mathrm{~N}\end{array}$ & $\begin{array}{l}\text { Aug } 28,1987, \text { p } 1040 \text {. } \\
\text { Aug } 15,1990, \text { p } 832 . \\
\text { Aug } 21,1991, \text { p } 942 .\end{array}$ & & & & \\
\hline
\end{tabular}

$41 \%$, and the last report places it at $35 \%$. Please note that allopathic residency statistics include both residents who first completed an osteopathic internship and those who entered allopathic residencies directly upon graduation. They also include residents in military programs that are approved by both the AOA and the Accreditation Council for Graduate Medical Education (ACGME). The statistics reported for osteopathic residents do not include any interns, even those in specialty internships. Note that overall these data show increases in the numbers of residents for both osteopathic and allopathic residency programs, but that the rate of increase has been less for osteopathic residency programs.

Figure 6 shows the number of residents in allopathic residencies in selected specialties, as reported in the annual "education issue" of
JAMA. The primary care specialties all show a linear increase in DOs in allopathic programs.

The AOA policies for approval of allopathic residency training were changed in 1988 , to no longer require applicants to document that osteopathic residency positions were not available. Table 6 shows the number of DOs in allopathic or military residency training who completed AOA-approved internships and are seeking AOA approval of subsequent residency training. Figure 7 shows that in many specialties the number of residents seeking approval of training immediately increased, particularly in those specialties that had denied most previous applications (notably general practice and internal medicine). However, for the 19911992 training year, these data tend to show a decline in applications for AOA approval, 


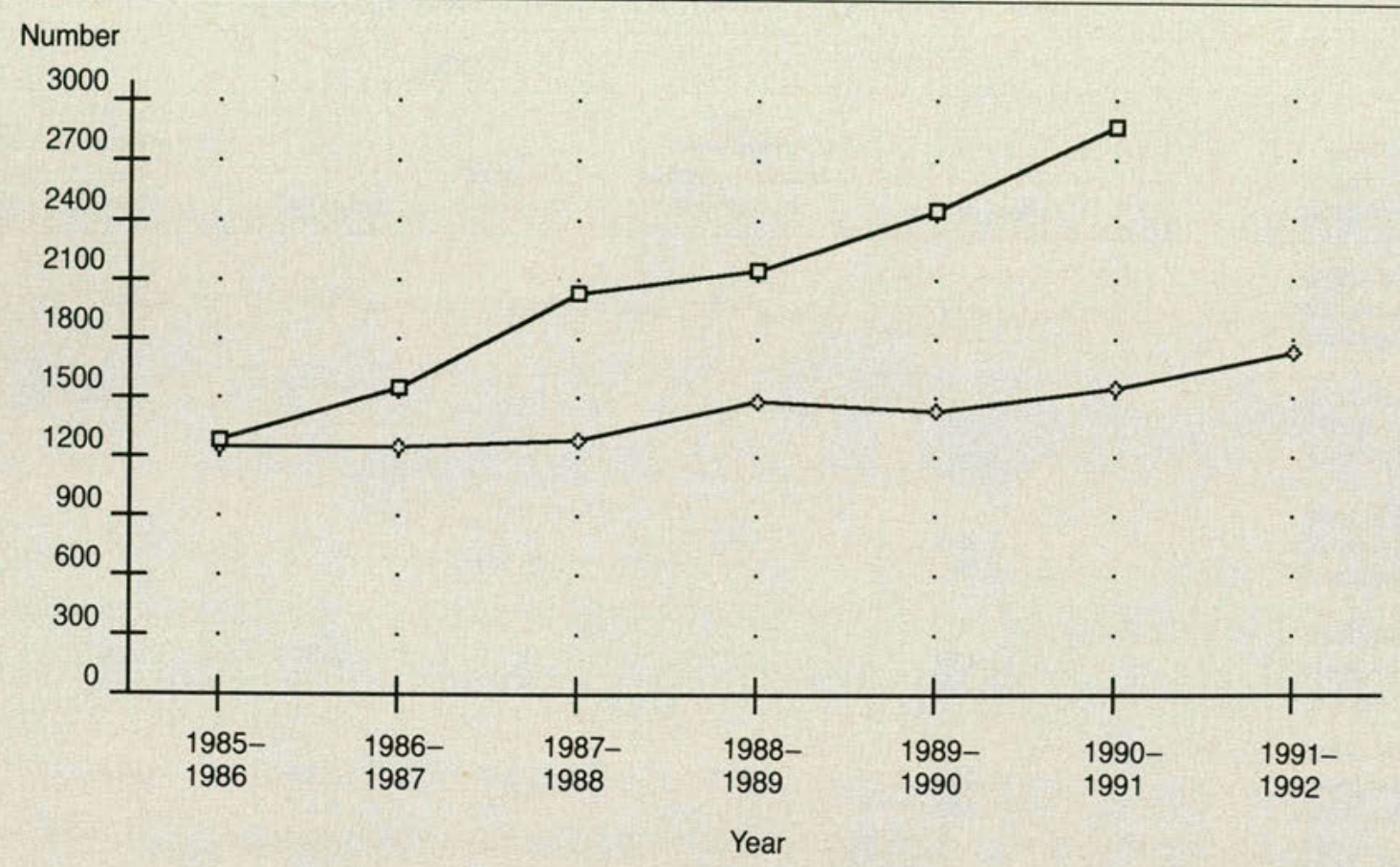

$\diamond$ Osteopathic residency programs $\quad \square$ Allopathic residency programs

Figure 5. DOs in residency training in osteopathic and allopathic institutions. ('Sources: AOA Data Base, and the annual education issue of JAMA, most recent edition, vol 266, No. 7, Aug 21, 1991; vol 264, No 7, Aug 15, 1990; and vol 258, No. 8, Aug 28, 1987.)

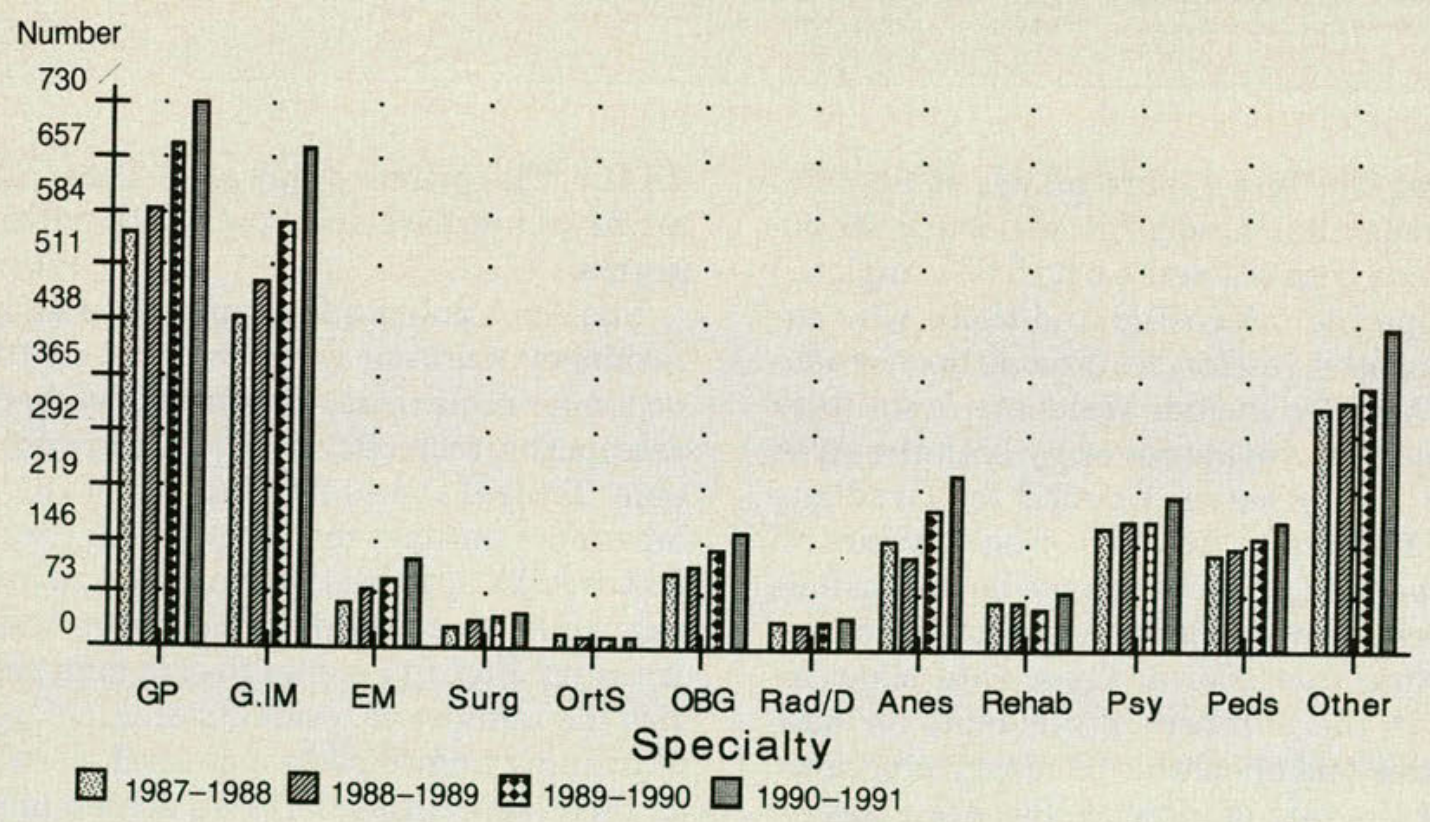

Figure 6. DOs in allopathic residency programs, by specialty. (Sources: The annual education issue of JAMA, most recent edition, vol 267, No. 7, Aug 21, 1991; and vol 264, No. 7, Aug 15, 1990.) 
Table 6

Nonosteopathic and Military Residents in AOA-Approved Programs (as of Sept 1, 1991)

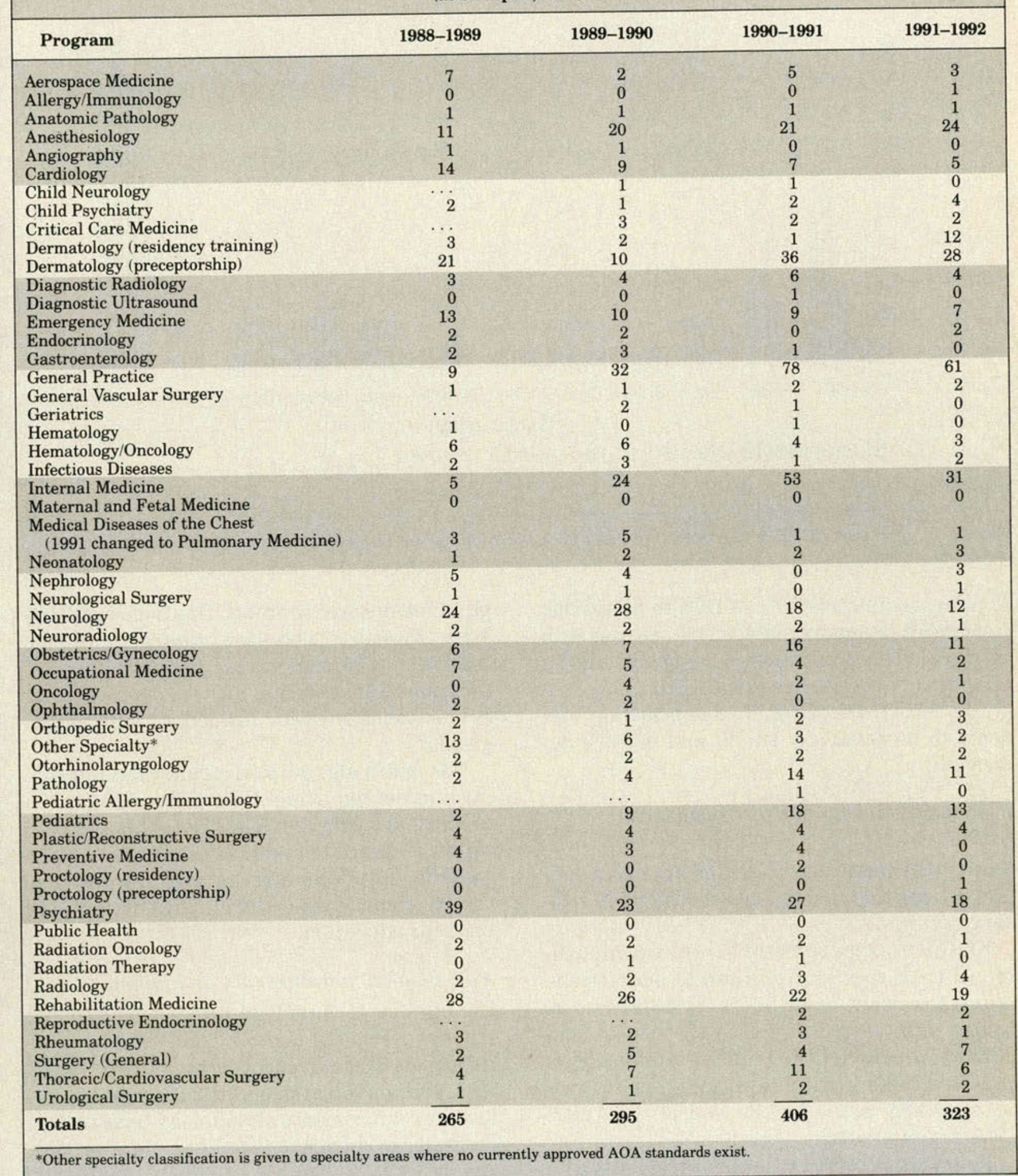




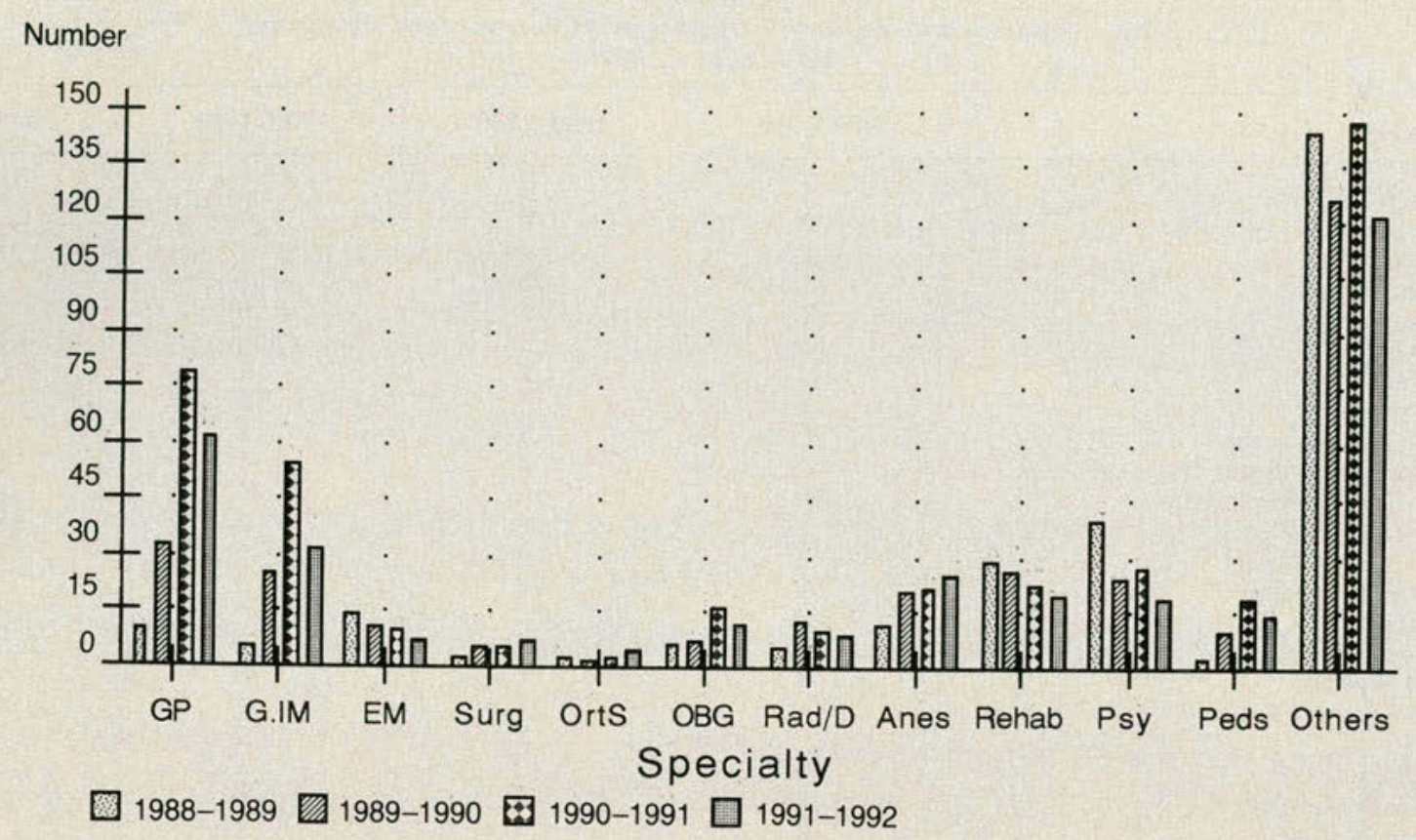

Figure 7. DOs seeking AOA approval of allopathic or military programs, by specialty, selected specialties. (Source: AOA Data Base.)

from approximately $17 \%$ of DOs in allopathic residencies to approximately $11 \%$ seeking such approval. The proportion of residents taking allopathic graduate medical education programs who are seeking "double boarding" appears to be relatively small, and may be decreasing.

\section{Policies regarding general residency training}

During the past year, the AOA approved several policies that had an impact on general residency training.

The Committee on Postdoctoral Training directed each specialty affiliate to address the issue of resident work hours in its programs. In the past year, this task has been accomplished in many of the training areas, and is expected to be instituted in all specialty and subspecialty areas by the end of the 19911992 training year.

Policy was adopted to prevent residents who unilaterally break contracts with osteopathic graduate medical training programs from gaining approval of any subsequent nonosteopathic graduate medical training. This policy will prevent physicians who have arbitrarily broken contracts with osteopathic graduate medical programs from entering into the approval process for nonosteopathic residency training programs.

The Board also adopted a policy recommending (but not requiring) financial compensation of residency program directors. This compensation is meant to stabilize the position of the residency program director and acknowledge the physician's expertise in patient care and resident education.

\section{New residency documents and policies}

Changes in terminology have converted the name of previously approved programs in medical diseases of the chest to pulmonary medicine, and modifications in the curriculum and faculty requirements of radiology have caused programs to change to diagnostic radiology programs.

Policies have been adopted in dermatology which will recognize only new residency programs and prohibit the approval of any pre- 
Table 7

Physicians Receiving Certification 1987 to 1991

(as of Aug 1, 1991)

\begin{tabular}{|c|c|c|c|c|c|c|c|c|c|c|c|}
\hline & 1987 & 1988 & 1989 & 1990 & 1991 & & 1987 & 1988 & 1989 & 1990 & 1991 \\
\hline Allergy and Immunology & 0 & 0 & 0 & 0 & 0 & Orofacial Plastic Surgery & 0 & 2 & 0 & 0 & 0 \\
\hline Anatomic Pathology & 3 & 2 & 4 & 2 & 2 & Orthopedic Surgery & 20 & 21 & 24 & 30 & 26 \\
\hline $\begin{array}{l}\text { Anatomic Pathology } \\
\text { and Laboratory Medicine }\end{array}$ & & & & & & Osteopathic Manipulative & & & & & \\
\hline $\begin{array}{l}\text { and Laboratory Medicine } \\
\text { Anesthesiology }\end{array}$ & 0 & $\begin{array}{r}0 \\
14\end{array}$ & 1 & 0 & 2 & & 0 & $\begin{array}{l}3 \\
2\end{array}$ & $\begin{array}{l}1 \\
2\end{array}$ & $\begin{array}{l}3 \\
4\end{array}$ & 24 \\
\hline $\begin{array}{l}\text { Anesthesiology } \\
\text { Cardiology }\end{array}$ & $\begin{array}{l}19 \\
13\end{array}$ & $\begin{array}{r}14 \\
8\end{array}$ & $\begin{array}{l}32 \\
12\end{array}$ & $\begin{array}{l}22 \\
15\end{array}$ & $\begin{array}{l}30 \\
19\end{array}$ & $\begin{array}{l}\text { Otorhinolaryngology } \\
\text { Otorhinolaryngology and }\end{array}$ & 0 & 2 & & 4 & \\
\hline Child Neurology & 1 & 0 & 0 & 0 & 0 & Orofacial Plastic Surgery & 7 & 7 & 8 & 12 & 8 \\
\hline Child Psychiatry & 1 & 1 & 1 & 0 & 4 & Pediatrics & 20 & 16 & 12 & 15 & 8 \\
\hline Dermatology & 3 & 7 & 5 & 5 & 9 & Plastic and Reconstructive & & & & & \\
\hline Diagnostic Radiology & 16 & 25 & 16 & 17 & 15 & Surgery & 0 & 0 & 1 & 1 & 0 \\
\hline Emergency Medicine & 38 & 30 & 34 & 40 & 51 & Preventive Medicine/ & & & & & \\
\hline Endocrinology & 1 & 2 & 1 & 1 & 0 & Aerospace Medicine & 1 & 2 & 3 & 3 & 2 \\
\hline Gastroenterology & 7 & 5 & 4 & 9 & 9 & Preventive Medicine & & & & & \\
\hline Gynecologic Oncology & 0 & 1 & 0 & 0 & 0 & and Public Health & 4 & 0 & 5 & 3 & 1 \\
\hline General Practice & 285 & 384 & 497 & 478 & $289^{*}$ & Preventive Medicine/ & & & & & \\
\hline General Vascular Surgery & 0 & 9 & 6 & 4 & 3 & Occupational Medicine/ & & & & & \\
\hline Hematology & 2 & 0 & 2 & 2 & 2 & Environmental Medicine & 5 & 6 & 5 & 4 & 6 \\
\hline Hematology and Oncology & 0 & 0 & 0 & 0 & 0 & Proctology & 2 & 1 & 0 & 2 & 2 \\
\hline Infectious Disease & 1 & 2 & 1 & 1 & 5 & Psychiatry & 8 & 8 & 11 & 10 & 16 \\
\hline Internal Medicine & 78 & 80 & 69 & 94 & 70 & Pulmonary Medicine & & & & & \\
\hline Laboratory Medicine & 2 & 1 & 2 & 0 & 3 & (Pre-1991-Medical Diseases & & & & & \\
\hline Maternal and Fetal Medicine & 0 & 1 & 1 & 0 & 1 & of the Chest) & $\ldots$ & & & & 9 \\
\hline Medical Diseases of the Chest & & & & & & Radiation Oncology & 1 & 1 & 0 & 0 & 2 \\
\hline (1991 changed to Pulmonary & & & & & & Radiology & 2 & 2 & 0 & 1 & 0 \\
\hline Medicine) & 7 & 7 & 6 & 7 & $\ldots$ & Rehabilitation Medicine & 4 & 6 & 11 & 7 & 6 \\
\hline Neonatology & 1 & 1 & 0 & 2 & 0 & Reproductive Endocrinology & 0 & 2 & 3 & 0 & 1 \\
\hline Nephrology & 4 & 4 & 2 & 4 & 3 & Rheumatology & 0 & 1 & 6 & 3 & 0 \\
\hline Neurological Surgery & 0 & 0 & 1 & 5 & 1 & Surgery (General) & 17 & 9 & 19 & 23 & 24 \\
\hline Neurology & 3 & 6 & 6 & 9 & 13 & Thoracic/Cardiovascular & & & & & \\
\hline Nuclear Medicine & 0 & 1 & 2 & 0 & 1 & Surgery & 4 & 5 & 3 & 0 & 4 \\
\hline Obstetrics and Gynecology & 11 & 13 & 15 & 22 & 25 & Urological Surgery & 6 & 6 & 6 & 7 & 9 \\
\hline $\begin{array}{l}\text { Oncology } \\
\text { Ophthalmology }\end{array}$ & $\begin{array}{r}4 \\
12\end{array}$ & $\begin{array}{l}2 \\
8\end{array}$ & $\begin{array}{r}2 \\
12\end{array}$ & $\begin{array}{r}1 \\
11\end{array}$ & $\begin{array}{r}7 \\
16\end{array}$ & $\begin{array}{l}\text { Total number of physicians } \\
\text { per year }\end{array}$ & 613 & 714 & 854 & 879 & $729 *$ \\
\hline
\end{tabular}

*Requirements for certification in general practice were expanded to require 2 years of residency training rather than 1 year. During this transition, few residents completed programs and, therefore, few applicants were available for certification in general practice in 1991.

ceptorship programs. This change will not affect currently approved preceptorship programs, but it will prevent establishment of any preceptorship programs under the direction of new preceptors.

New standards have been approved for training in combined emergency medicine/internal medicine; sports medicine; and surgical critical care. Standards were also approved in general practice in the fields of interest areas of adolescent and young adult medicine, and osteopathic sports medicine.

\section{Certification}

Specialty certification is awarded by the AOA Board of Trustees through the appropriate specialty boards and on recommendation from the Advisory Board for Osteopathic Specialists.
The Advisory Board was established in 1939 by action of the AOA Board of Trustees to meet the needs resulting from the growth of specialization in the osteopathic medical profession. The Advisory Board is composed of one representative from each of the 18 specialty boards, one representative from the Bureau of Professional Education, and a chairman and vice chairman appointed by the president of the AOA. One affiliate has nonvoting representation.

In addition to making recommendations to the Board of Trustees concerning certification of physicians, the Advisory Board makes recommendations concerning the rules, regulations, and procedures established by the specialty boards. The Advisory Board is also charged with providing recommendations con- 
cerning the establishment of new certifying boards and the assignment or transfer of specialty and/or subspecialty jurisdiction.

Action by the Board of Trustees in July 1991, clarified terminology regarding certification. "Certification" will be used for certification in a specialty or subspecialty and for certification of special proficiency in Osteopathic Manipulative Medicine, and the only other term that will be used by the AOA and the Advisory Board is "certificate of special recognition." The term "subspecialty" will refer only to areas eligible for certification, and "field of interest" will be used for training in areas not leading to certification. Documents using the terms "certificate of added qualification" or "certificate of competence" will be brought into compliance with this policy.

To respond to concerns about the length of the interval between the time a candidate completes requirements for certification and the date of final certification action by the AOA board of Trustees, policies were changed to make certification effective as of "the date of verification of successful completion of all specialty board requirements" by the respective specialty boards.

The Advisory Board has also been directed by the AOA Board of Trustees to further ex- amine the recertification process, with a goal of developing a uniform recertification process applicable to all specialties. This process is currently under way.

Other policy action, passed by the AOA House of Delegates, establishes a task force to study issues in graduate medical education, and places a moratorium on documents relating to issues of certification, new specialties, and the approval process and impact of approving new allopathic training programs for osteopathic graduate medical education, until this report is received in 1992. This resolution does not affect programs currently in place and any adjustments made to those programs.

Table 7 shows the number of physicians certified for the past 4 years. The table shows a temporary decline in the number of physicians certified in general practice, resulting from implementation of the requirement of a 2-year residency in general practice and therefore few physicians meeting the requirements for certification during this transition.

\section{Summary}

Osteopathic graduate medical education is still in transition. The AOA Department of Education will continue to monitor and report on the impact of these changes. 